\title{
STUDI KASUS EKSISTENSI DIRI PESERTA DIDIK KELAS XII SMA NEGERI 4 SURAKARTA DALAM PENGGUNAAN MEDIA SOSIAL INSTAGRAM
}

\author{
Krisna Dwi Kartika, Ulya Makhmudah, Adi Dewantoro \\ Fakultas Keguruan dan Ilmu Pendidikan_Universitas Sebelas Maret \\ E-mail: krisnadwikartika@gmail.com
}

\begin{abstract}
Everyone has a different self-existence because existence is a personal property which it could not be replaced by anyone. This is reinforced by Sartre's opinion (Cervone \& Pervin, 2011: 262) that "humans are completely different." Existence comes from existentialism thought by Soren Kierkagard. Kierkagard (Dagun, 1990: 24) asserts that the most important thing for human in life is their existence. Self-existence in cyberspace is done through Instagram social media. Instagram is the most popular social media used (Supratman, 2018: 55). This study aimed to describe the profile and form of self-existence in the use of Instagram social media. There were three students with the initials ANS, MAP and TFA. Those students were selected using a judgmental sampling technique with predetermined consideration. The approach used was a qualitative approach with case study method. The result of this study indicated that the three students showed their existence on Instagram according to their interest and skill also goal. They showed their existence by uploading photos/videos as lip sync, make up, make up tutorials, outfit of the day picture, song covers, having opinion on certain issue and they did some activities as looking for the latest information, religion, culinary, and make up. The three of them felt the benefits after showing their existence on Instagram social media.
\end{abstract}

Keywords: self-existence, instagram social media

\begin{abstract}
Abstrak
Setiap orang memiliki eksistensi diri yang berbeda karena eksistensi merupakan miliki pribadi yang keberadaanya tidak dapat digantikan oleh siapapun. Hal ini diperkuat dengan pendapat Sartre (Cervone \& Pervin, 2011: 262) yaitu "manusia sepenuhnya berbeda." Eksistensi berasal dari pemikiran eksistensialisme yang dikemukakan oleh Soren Kierkagard. Kierkagard (Dagun, 1990: 24) menegaskan bahwa hal yang penting bagi manusia dalam hidup adalah eksistensi yang dimiliki. Eksistensi diri di dunia maya dilakukan melalui media sosial instagram. Instagram merupakan media sosial yang paling popular yang digunakan (Supratman, 2018: 55). Penelitian ini bertujuan untuk mendeskripsikan profil dan bentuk eksistensi diri dalam penggunaan media sosial instagram. Terdapat tiga peserta didik yang berinisial ANS, MAP dan TFA. Ketiganya dipilih menggunakan teknik judgmental sampling dengan pertimbangan yang telah ditentukan. Pendekatan yang digunakan adalah kualitatif dengan metode studi kasus. Hasil penelitian ini diketahui bahwa ketiga subjek menunjukkan eksistensi diri di media sosial instagram sesuai dengan minat dan bakat serta tujuan masingmasing. Mereka menunjukkan eksistensi diri dengan cara mengunggah foto/video seperti lipsync make up, tutorial make up, foto outfit of the day, cover lagu, beropini tema tertentu dan melakukan aktivitas seperti mencari berbagai informasi terkini, keagamaan, kuliner, dan make up. Ketiganya merasakan manfaat setelah menunjukkan eksistensi diri di media sosial instagram.
\end{abstract}

Kata kunci: eksistensi diri, media sosial instagram 


\section{PENDAHULUAN}

Eksistensi memiliki arti pengakuan orang lain terhadap diri seseorang dalam suatu lingkungan. Seseorang yang memiliki eksistensi diri yang baik akan diakui keberadaannya dan diperhitungkan kehadirannya di lingkungan tersebut (Caniago, 2017: 1). Setiap orang memiliki eksistensi yang berbeda karena eksistensi merupakan milik pribadi yang keberadaanya tidak dapat digantikan oleh siapapun. Mengingat di dunia tidak ada dua individu yang identik sehingga apa yang dialami dan dirasakan setiap orang berbeda. Hal ini diperkuatkan dengan pendapat Sartre (Cervone \& Pervin, 2011: 262) yaitu "manusia sepenuhnya berbeda."

Eksistensi berasal dari pemikiran eksistensialisme yang dikemukakan oleh Soren Kierkagaard. Kierkagaard (Dagun, 1990: 24) menegaskan bahwa hal yang penting bagi manusia dalam hidup adalah eksistensi yang dimiliki. Dagun (1990: 16) mengatakan "Eksistensialisme merupakan filsafat yang memandang segala gejala yang berfokus pada eksistensi. Titik sentralnya adalah manusia. Eksistensi pada manusia adalah cara manusia berada di dunia ini." Hal ini dimaksudkan bahwa cara manusia untuk hidup di dunia setiap orang berbeda berdasarkan pengalaman yang dialami dan tujuan hidup yang dipilih. Setiap manusia memiliki kebebasan untuk menentukan jalan hidupnya sendiri. Mereka juga harus bertanggung jawab atas pilihan yang telah dibuat.

Fenomena tentang eksistensi diri sudah sangat melekat dalam diri seseorang khususnya pada kalangan remaja. Remaja merupakan masa peralihan dari masa kanak-kanak untuk menuju masa dewasa tetapi usia remaja ini juga belum bisa dikatakan sebagai seseorang yang telah dewasa. Eksistensi diri remaja terjadi di dunia nyata dan dunia maya.
Eksistensi di dunia nyata berkaitan dengan pengakuan yang diterima seseorang dari orang lain di lingkungannya. Manusia dengan lingkungan merupakan satu kesatuan yang dikenal dengan bahasa Jerman yaitu "Dasein" berarti "untuk hadir disana." Feist, Feist \& Roberst (2017: 346) berpendapat bahwa "Dasein secara harfiah berarti untuk eksis di dunia dan umumnya ditulis sebagai Being-in-the-world." Eksistensi di dunia maya ditunjukkan dengan memiliki pengikut yang banyak, mengunggah foto atau video dan melakukan story serta aktivitas lain yang diunggah diakun instagram.

Arti media sosial yang sesuai dengan pernyataan Andres \& Michael (Cahyono, 2016: 142) adalah bentuk dari sebuah aplikasi dengan menggunakan internet sebagai pembukanya yang dibuat berdasarkan ideologi dan teknologi 2.0 dan memungkinkan untuk terjadinya penciptaan dan adanya pertukaran konten yang dihasilkan oleh pengguna. Terdapat beberapa media sosial yang aktif digunakan oleh kebanyakan orang yaitu instagram, line, whatsapp, facebook, snapchat, twitter, dan ask.fm. Instagram merupakan media sosial yang paling populer yang digunakan (Supratman, 2018: 55).

Menurut pendapat Pertiwi (2019) jumlah pengguna instagram sampai bulan November 2019 sebanyak 61.610.000 sesuai dengan data NapoleonCat yang merupakan salah satu perusahaan analisa sosial media di Warsawa, Polandia. Oleh karena itu, instagram menjadi media sosial yang digunakan sebagai media untuk menunjang eksistensi diri remaja. Instagram merupakan aplikasi yang digunakan untuk berbagi foto dengan kemudian menambahkan filter pada foto lalu membagikannya dilayanan jejaring sosial (Islami, 2018: 4). Fokus dari pembuatan aplikasi instagram ini yaitu mengembangkan aplikasi yang ada di telepon genggam yang mana aplikasi ini 
mudah untuk diakses oleh siapapun (Caniago, 2017: 10).

Eksistensi diri yang sebenarnya adalah eksistensi yang memberikan manfaat dan dorongan semangat untuk orang lain. Hal ini sesuai dengan pendapat Dagun (2000: 17) bahwa "Bereksistensi berarti menciptakan dirinya secara aktif." Bereksistensi diri berarti seseorang berbuat, merencanakan sesuatu yang membuat dirinya menjadi lebih dari keadaan sebelumnya dengan menjadi pribadi yang positif seperti menjadi juara lomba tingkat internasional, menunjukkan karya atau kreativitas yang dimiliki dan membagikan nasihat berupa quotes.

Perbedaan yang terjadi antara bentuk eksistensi di lingkungan remaja saat ini dengan eksistensi yang seharusnya akan berakibat pada kepuasan yang dirasakan oleh pengguna instagram tersebut berkurang. Mengingat bahwa eksistensi yang diperoleh dari hal yang tidak baik atau tidak seharusnya akan membuat orang yang melihat memberikan penilaian yang kurang menyenangkan dan candaan yang berisi ejekan sehingga dapat menyakiti perasaan orang lain. Hal ini termasuk cyberbullying yaitu penindasan yang dilakukan seseorang di dunia cyber (Octavia, 2017:13). Sedangkan eksistensi yang diperoleh dari hal yang membanggakan dan bermanfaat akan membuat orang yang melihat merasa terbantu dan juga memberikan penilaian yang baik dan bisa dikenang secara positif.

Berdasarkan penjelasan di atas terdapat penelitian dari Fauji (2018) yang membahas mengenai eksistensi diri. Penelitian ini berjudul "Pengaruh Penggunaan Instagram Terhadap Eksistensi Diri Pada Siswa-Siswi SMA Wachid Hasyim Surabaya." Hasil dari penelitian ini adalah terdapat pengaruh yang signifikan dalam penggunaan instagram untuk menunjang eksistensi diri.

Berdasarkan hasil penelitian yang telah dilakukan sebelumnya oleh Fauji, Aprilia dan wawancara dengan salah satu peserta didik berinisial SF mengenai eksistensi diri. Serta observasi yang dilakukan peneliti terhadap setiap akun instagram peserta didik kelas XII. Hasilnya peneliti menemukan tiga peserta didik yang menunjukkan eksistensi diri di media sosial instagram. Pemilihan peserta didik ini berdasarkan pertimbangan yang telah ditentukan melalui teknik purposive sampling yaitu peserta didik kelas XII di SMA Negeri 4 Surakarta, memiliki akun media sosial instagram dengan minimal 1000 pengikut, menunjukkan eksistensi diri yang mengarah pada keberadaan yang otentik seperti mempromosikan bisnis, menunjukkan bakat dan minat yang dimiliki. Peserta didik tersebut berinisial ANS, MAP dan TFA. Ketiganya saat ini duduk di bangku kelas XII.

ANS memiliki akun instagram dengan jumlah pengikut sebanyak 1648 dan ia mengunggah foto atau video make up serta mempromosikan bisnis yang dimilikinya melalui instagram stories. Selanjutnya peserta didik MAP memiliki jumlah pengikut sebanyak 2499 dan sebanyak 606 akun yang diikuti. MAP mengunggah foto dengan menggunakan make up dan pakaian yang popular di media sosial instagram-nya serta ia membantu untuk mempromosikan bisnis yang dimiliki temannya. Sedangkan TFA mengunggah foto kebersamaan dengan teman dan keluarga, mengunggah video cover lagu serta membagikan hasil kegiatan webinar melalui instagram stories. TFA telah memiliki sebanyak 5928 dan 1698 akun yang diikuti. Berdasarkan uraian di atas mengenai eksistensi yang dilakukan peserta didik berinisial ANS, MAP dan TFA, maka 
peneliti tertarik untuk melakukan penelitian mengenai profil dan bentuk eksistensi diri peserta didik dalam penggunaan media sosial instagram. Hal tersebut dikarenakan eksistensi merupakan fenomena yang saat ini sedang dialami oleh individu yang berkaitan dengan upaya untuk menunjukkan keberadaan dirinya di media sosial instagram.

Setiap individu memiliki cara masing-masing untuk menunjukkan eksistensinya. Pendekatan kualitatif dengan metode studi kasus dirasa cocok untuk mengkaji penelitian ini. Mengingat studi kasus merupakan penelitian yang digunakan untuk menyelidiki fenomena yang bersifat kontemporer atau yang terjadi pada masa sekarang. Penelitian ini berjudul "Studi Kasus Eksistensi Diri Peserta Didik Kelas XII SMA Negeri 4 Surakarta dalam Penggunaan Media Sosial Instagram."

\section{METODE PENELITIAN}

Penelitian ini menggunakan metode studi kasus. Menurut Yin (2003: 13) studi kasus adalah penelitian empiris yang digunakan untuk menyelidiki fenomena yang bersifat kontemporer terkait kehidupan nyata pada seseorang. Sumber data terbagi menjadi dua yaitu data primer dan sekunder. Data primer yang digunakan adalah wawancara dan observasi dengan tiga subjek yang berinisial ANS, MAP dan TFA. Sedangkan, data sekunder berasal dari wawancara dengan teman sebaya subjek yang berinisial BY, M dan SF serta hasil screenshot unggahan foto atau video dari akun media sosial instagram subjek. Teknik analisis data menggunakan pendapat dari Miles dan Hubermen (2007: 16) yang terdiri dari tiga tahap yaitu reduksi data, penyajian data dan penarikan kesimpulan atau verifikasi. Adapun prosedur dalam penelitian studi kasus ini terdiri dari tiga tahap yang berdasarkan pendapat Yin (2003: 50) yaitu (1) tahap mendefinisikan dan perancangan, (2) tahap persiapan, pengumpulan dan analisis, (3) tahap analisis dan kesimpulan.

\section{HASIL DAN PEMBAHASAN}

Berdasarkan pada hasil penelitian maka dapat dianalisis sesuai dengan rumusan masalah pada bab I, yaitu bagaimana profil dan bentuk eksistensi diri peserta didik dalam penggunaan media sosial instagram.

\section{Profil eksistensi diri peserta didik dalam penggunaan media sosial instagram.}

Eksistensi diri merupakan segala hal yang dilakukan oleh individu dalam mengarahkan dirinya pada keberadaan yang otentik artinya memiliki kesadaran akan kelebihan dan kekurangan diri, bertindak atas pilihannya sendiri dan bertanggung jawab atas pilihan yang diambil (Abidin, 2002: 12). Eksistensi diri dapat diartikan sebagai tindakan individu untuk menunjukkan keberadaan dirinya dengan memahami kelebihan dan kekurangan yang dimiliki serta memiliki tujuan yang ingin dicapai dan bertanggung jawab atas pilihannya. Ketiga subjek beranggapan eksistensi diri di media sosial instagram merupakan hal yang penting. Subjek II merasa eksistensi diri di media sosial instagram telah mempermudah dirinya untuk mencari informasi. Sedangkan, subjek I dan III merasakan bahwa eksistensi diri di media sosial instagram merupakan upaya untuk menunjukkan siapa dirinya kepada orang lain.

Ketiga subjek menyadari kelebihan dan kekurangan serta tujuan 
yang ingin dicapai. Ketiganya menunjukkan eksistensi diri sesuai dengan kelebihan dan bidang yang diminati. Subjek I dan subjek II memiliki minat dalam hal make up, keduanya bercita-cita menjadi seorang beauty vlogger. Selanjutnya, subjek III memiliki cita-cita sebagai aktivis yang bermanfaat dan sukses di bidang musik maupun public speaking. Sukmasari (Rizki, 2017: 4) mengatakan bahwa pemberian like dan komentar dari orang lain setelah mengunggah foto atau video di media instagram merupakan aspek yang dapat mendorong harga diri yang dimiliki individu. Menurut Valkenburg et al (Jan, Soomro \& Ahmad, 2017: 330) adanya umpan balik dari orang lain yang bersifat negatif akan menyebabkan penurunan pada harga diri individu, sedangkan umpan balik yang bersifat positif akan meningkatkan harga diri individu.

Ketiga subjek memperoleh apresiasi dari orang lain berupa like, komentar dan jumlah pengikut yang meningkat. Sehingga ketiganya mengucapkan terima kasih atas pujian yang diberikan dan mempertimbangkan kritik serta saran yang ada.

Ketiga subjek memiliki teman yang selalu memberikan dukungan ketika menunjukkan eksistensi diri di media sosial instagram. Seperti yang diungkapkan oleh Berndt (Ja'fin, 2012: 13) memiliki teman sebaya dapat memberikan keuntungan bagi individu, namun ada pula yang justru merugikan. Menurut Hurlock (Ja'fin, 2012: 14) adanya dukungan yang diberikan oleh teman sebaya merupakan hal yang sangat penting, hal ini dikarenakan remaja memiliki rasa ingin diterima dalam kelompoknya, sehingga ketika teman memberikan masukan, akan cenderung untuk mempertimbangkannya. Hal tersebut didukung dengan pendapat Erikson (Nazri \& Latiff, 2019: 302) bahwa pertemanan memiliki peran yang penting dalam penerimaan sosial pada individu. Subjek I memiliki teman yang selalu memberikan dukungan terhadap bisnisnya. Subjek II merasa hanya orang lain yang dapat memberikan penilaian, sehingga ia selalu meminta pertimbangan teman dan pacar terlebih dahulu. Subjek III merasa dukungan yang diberikan ibu membuat ia menjadi seseorang yang percaya diri untuk menunjukkan siapa dirinya. Adanya dukungan dari keluarga merupakan hal yang penting untuk meningkatkan rasa percaya diri pada subjek. Kepercayaan diri merupakan salah satu ciri dari eksistensi diri. Hal tersebut sesuai dengan yang diungkapkan Taylor (Rifai, 2014: 7) dukungan keluarga adalah bantuan yang diterima oleh anggota lain, berupa kenyamanan secara fisik dan psikologis agar terhindar dari stres. Selain itu, Sarafino dan Heansarling (Rifai, 2014: 7) juga mengungkapkan terdapat empat aspek dukungan keluarga yaitu aspek emosional, penghargaan, instrumental dan partisipasi. Subjek I memiliki keluarga yang suportif, hal ini ditunjukkan dengan pemenuhan fasilitas, tenaga dan saran yang diberikan. Sedangkan subjek III mengatakan bahwa keberhasilan yang dicapai berkat dukungan keluarga terutama ibu.

Ketiga subjek merasakan manfaat ketika menunjukkan eksistensi diri di media sosial instagram. Subjek I merasa menjadi dikenal banyak orang dan bisnisnya semakin berkembang. Subjek II merasa eksistensi diri 
memudahkan dirinya untuk mencari informasi terkini. Subjek juga dapat mengenal orang banyak dari instagram dan memperoleh informasi tentang pendidikan. Selanjutnya, subjek III merasakan manfaat yaitu memperoleh banyak tawaran untuk bernyanyi, memperoleh band serta berpartisipasi dalam perlombaan. Selain itu, subjek juga diminta untuk menjadi pembicara guna membagikan pengalamannya di webinar.

\section{Bentuk eksistensi diri dalam penggunaan media sosial instagram bagi peserta didik SMA Negeri 4 Surakarta}

Menurut Ellison dkk (Eginli \& Tas, 2018: 83) konsep jejaring sosial merupakan media yang dapat digunakan untuk menjalin hubungan bisnis, pertemanan dengan orang baru dan berkumpul dengan orang yang memiliki minat yang sama. Ketiga subjek menunjukkan eksistensi diri di media sosial instagram sesuai dengan minat yang dimiliki. Berdasarkan pendapat Wettherington (Aisyah, 2018: 54) minat seseorang muncul akibat dari adanya perhatian yang diterima dari orang lain, hal tersebut membuatnya memiliki sikap yang positif dan rasa senang terhadap hal yang diminati. Dalam hal ini, subjek I dan subjek II memiliki minat dalam hal make up. Sedangkan subjek III memiliki minat pada bidang musik dan public speaking.

Adanya media sosial instagram dapat digunakan subjek untuk menyalurkan minat yang dimiliki, hal ini sama halnya dengan upaya subjek untuk mempromosikan diri sendiri kepada orang lain. Menurut Hearn (Arriagada \& Ibanez, 2020: 4) aktivitas yang dilakukan seseorang dalam upaya untuk mempromosikan dirinya menjadi "bentuk kerja afektif imateriil yang sengaja dilakukan oleh individu untuk mengumpulkan perhatian, reputasi dan berpotensi untuk memperoleh keuntungan."

Berdasarkan pendapat Vogel (Jiang \& Ngien, 2020: 2) seseorang ketika menunjukkan dirinya di media sosial cenderung melakukannya secara selektif guna menunjukkan eksistensi diri sesuai dengan apa yang disukai. Subjek I menunjukkan dirinya melalui lipsync make up video, tutorial make up, dan foto hasil make up secara close up. Serta beberapa foto liburan bersama keluarga. Subjek II menunjukkan dalam bentuk video make up dan sering membagikan foto menggunakan pakaian yang sedang popular. Subjek III menunjukkan dirinya dengan cara membuat cover lagu, melakukan live instagram untuk berbagi pengalaman dan beropini tentang hak dan kewajiban anak, genre equity serta lingkungan.

Terdapat beberapa fitur di media sosial instagram yang digunakan oleh ketiga subjek seperti explore, instagram direct dan instagram stories. Ketiga subjek menggunakan fitur explore untuk mencari inspirasi dan informasi. Subjek I mencari inspirasi tentang video make up. Subjek II mencari berbagai informasi diskon. Selanjutnya, subjek III mencari informasi tentang event, lomba, kuliner dan keagamaan. Instagram dapat dijadikan sebagai market bagi seseorang yang ingin memperluas jangkauan bisnisnya. Menurut Muttaqin (Kurniawan, 2017: 220) instagram marketing merupakan aktivitas marketing yang dilakukan seseorang dengan memanfaatkan semua fasilitas atau fitur yang disediakan instagram. Hal tersebut 
dilakukan dengan tujuan untuk meningkatkan penjualan dan menjalin komunikasi dengan pembeli.

Ketiga subjek juga mempromosikan bisnis yang dimiliki sendiri ataupun teman dengan memanfaatkan fitur instagram stories pada akun masingmasing. Subjek I juga membagikan kegiatan yang dilakukan sebagai Putri Smaracatur dan beberapa foto liburan. Subjek II memilih untuk membagikan video tiktok dan kebersamaan dengan teman. Sedangkan, subjek III membagikan hasil kegiatan webinar dan kesehariannya.

Ketiga subjek memiliki cara sendiri untuk mempertahankan eksistensi diri di media sosial instagram. Subjek I memilih untuk lebih rajin dalam mengunggah foto atau video serta sering mempromosikan bisnis. Sedangkan subjek II memilih untuk mengikuti zaman seperti bermain tiktok yang kemudian dibagikan melalui instagram stories. Selanjutnya, subjek III memilih untuk mencari dan membagikan keunikan dirinya. Interaksi yang dilakukan oleh ketiga subjek dengan pengguna lain dengan cara memberikan like, membalas direct message, melakukan live instagram dan membuat question box di instagram stories.

\section{KESIMPULAN}

Berdasarkan hasil pembahasan yang diperoleh dari penelitian tentang eksistensi diri peserta didik SMA Negeri 4 Surakarta, maka dapat diperoleh simpulan sebagai berikut:

1. Deskripsi profil eksistensi diri ketiga subjek memiliki cara masingmasing untuk menunjukkan eksistensi diri di media sosial instagram yaitu sesuai dengan minat, bakat dan tujuan yang ingin dicapai. ANS dan MAP memiliki minat dalam hal make up, keduanya bercita-cita menjadi beauty vlogger. Sedangkan TFA memiliki bakat di bidang musik dan minat dalam berorganisasi, hal tersebut membuat ia ingin menjadi seorang aktivis yang bermanfaat dan sukses di bidang musik dan public speaking. ANS, MAP dan TFA memperoleh dukungan dari keluarga dan teman, sehingga menjadikan ketiganya lebih semangat untuk menunjukkan eksistensi dirinya. Selain itu, mereka merasakan manfaat ketika menunjukkan eksistensi diri di media sosial instagram.

2. Deskripsi bentuk eksistensi diri ketiga subjek memiliki kesamaan yaitu mengunggah foto atau video sesuai dengan minat yang dimiliki, membagikan kebersamaan dengan keluarga atau teman, melakukan live instagram, mengunggah instagram stories dan mempromosikan bisnis serta melakukan aktivitas seperti mencari berbagai informasi. Selain itu, Ketiga subjek juga memanfaatkan fitur yang tersedia di media sosial instagram untuk menjalin interaksi dengan pengguna lain.

\section{REFERENSI}

Abidin, Z. (2002). Analisis Eksistensial Untuk Psikologi \& Psikiatri. Bandung: Refika Aditama

Aisyah, S. (2018). Pemanfaatan Bakat dan Minat Siswa dalam Layanan Penempatan dan Penyaluran di MAN 3 Medan Tahun Ajaran 2017/2018. Skripsi Dipublikasi. Sumatera Barat. Universitas Islam Negeri Sumatera Utara.

Aprilia, N. (2016). Instagram Sebagai Ajang Eksistensi Diri Studi 
Fenomenologis Mengenai

Pengguna Instagram Sebagai Ajang Eksistensi Diri Pada Mahasiswa Ilmu Komunikas Fisip Unpas. Skripsi Dipublikasi. Bandung. Universitas Pasundan Bandung.

Arriagada, A \& Ibanez, F. (2020). "You Need At Least One Picture Daily, if Not, You're Dead": Content Creators and Platfrom Evoluation in the Social Media Ecology. Sage Journals, 6, 4.

Cahyono, A. S. (2016). Pengaruh Media Sosial Terhadap Perubahan Sosial Masyarakat Di Indonesia (Versi Elektronik). Jurnal Unita, 9 (1), 142.

Caniago, R. L. (2017). Selfie Sebagai Wujud Meningkatkan Eksistensi Diri Mahasiswa Melalui Akun Instagram. Skripsi Dipublikasi. Purwokerto. Institut Agama Islam Negeri Purwokerto.

Cervone, D., \& Pervin, L.A. (2011). Kepribadian: Teori dan Penelitian. Jakarta: Salemba Humanika

Dagun, S.M. (1990). Filsafat Eksistensialisme. Jakarta: Rineka Cipta.

Eginli, A. T., \& Tas, N. O. (2018). Interpersonal Communication in Social Networking Sites: An Investigation in the Framework of Uses and Gratification Theory. Online Journal of Communication and Media Technologies, 8 (2), 83.

Fauji, S. (2018). Pengaruh Penggunaan Instagram Terhadap Eksistensi Diri pada Siswa-Siswi SMA Wachid Hasyim 1 Surabaya. Skripsi Dipublikasi. Surabaya: Sekolah
Tinggi Ilmu Komunikasi Almamater Wartawan Surabaya. Feist, J., Feist, G.J., \& Roberts, T.A. (2017). Teori Kepribadian. Jakarta: Salemba Humanika.

Islami, A. N. (2018). Instagram: Media Sosial dan Eksistensi Diri Remaja Berprestasi Di Kota Palu (Versi Elektronik). Jurnal Kinesik, 5 (3), 4.

Jan, M., Soomro, S. A., \& Ahmad, N. (2017). Impact of Social Media on Self Esteem. European Scientific Journal, 13 (23), 330.

Ja'fin, A. 2012. Pengaruh Peer Support Terhadap

Penyalahgunaan Alkohol di Madrasah Aliyah Nurul Islam Bades Pasirian Lumajang. Skripsi Dipublikasi. Malang: Universitas Islam Negeri Maulana Malik Ibrahim Malang.

Jiang, S. \& Ngien, A. (2020). The Effects of Instagram Use, Social Comparison, and Self-Esteem in Social Anxiety: A Survey Study in Singapore. Sage Journals, 6, 2.

Kurniawan, P. (2017). Pemanfaatan Media Sosial Instagram Sebagai Komunikasi Pemasaran Modern pada Batik Burneh. Journal of Management Studies, 11 (2), 220.

Miles, M. B \& Huberman, A. M. (2007). Analisis Data Kualitatif. Jakarta: Universitas Indonesia.

Nazri, S. M., \& Latiff, Z. A. (2019).

Exploring Desires and Maneuvering on Instagram Life: A Phenomenology Study. International Cenference on Communication, Culture and Media Studies.

Octavia, A.P. (2017). Cyberbullying dan Motif Remaja dalam Melakukannya

(Versi 
Elektronik). Jurnal Komunikasi Massa, (1).

Pertiwi, W.K. (2019, 23 Desember). Sebanyak Inikah Jumlah Pengguna Instagram di Indonesia. Kompas. Diperoleh pada 26 Januari 2020, dari https://www.google.com/amp/s/a mp.kompas.com/tekno/read/2 019/12/23/14020057/sebanyakinikah-jumlah-penggunainstagram-di-indonesia

Rifai, M. E. (2014). Hubungan Kepercayaan Diri dan Dukungan Keluarga Dengan Kecemasan Matematika. Naskah Dipublikasi. Surakarta: Program Pascasarjana Universitas Muhammadiyah Surakarta

Rizki, A. I. (2017). Hubungan Antara Intensitas Penggunaan Media Sosial Instagram Dengan Harga Diri. Skrispi Dipublikasi. Surakarta: Universitas Muhammadiyah Surakarta.

Supratman, L.C. (2018). Penggunaan Media Sosial oleh Digital Native (Versi Elektronik). Jurnal Ilmu Komunikas, 15 (1), 55.

Yin, R. K. (2003). Case Study Research Design and Methods. Sage Publications: California 